\title{
ANALISIS KINERJA KEUANGAN DENGAN PENDEKATAN METODE ECONOMIC VALUE ADDED (EVA) PADA PT. BLUE BIRD Tbk PERIODE 2014-2018
}

\author{
${ }^{1)}$ Zeze Zakaria Hamzah, ${ }^{2)}$ Sarah Awaliyah \\ ${ }^{1)}$ Dosen Program Studi Manajemen, STIE Dewantara \\ Jl. Raya Pemda Bojong Depok Baru III, Karadenan, Cibinong, Bogor, Jawa Barat 16913,Indonesia \\ Email: zeze.zakaria@dewantara.ac.id \\ ${ }^{2)}$ Alumni Program Studi Manajemen, STIE Dewantara \\ Jl. Raya Pemda Bojong Depok Baru III, Karadenan, Cibinong, Bogor, Jawa Barat 16913,Indonesia \\ Email: sarahawaliyah5@gmail.com
}

\begin{abstract}
This study aims to determine the financial performance of PT. Blue Bird Tbk which was examined based on analysis using the Economic Value Added (EVA) method during 2014 2018 period. Quantitative approach was used and the study population is also a sample of research is the financial statements of the last five years (2014-2018). Data collection is done by taking documentation from the official website and then analyzed using the EVA method which consists of NOPAT analysis, Invested Capital, WACC, Capital Charges. The results showed that Economic Value Added (EVA) at PT. Blue Bird Tbk in the 2014-2018 period got EVA value $<0$ meaning that the company could not create economic value added. This happened because the level of capital costs is higher than the rate of return on operating profits of the company due to new competitors in the form of online transportation.
\end{abstract}

Keywords: Economic Value Added (EVA), NOPAT, Invested Capital, WACC, Capital Charges, Financial Performance.

\section{ABSTRAK}

Penelitian ini bertujuan untuk mengetahui kinerja keuangan PT. Blue Bird Tbk yang diteliti berdasarkan analisis dengan menggunakan metode Economic Value Added (EVA) periode 2014 - 2018, jenis yang digunakan dalam penelitian ini adalah kuantitatif. Populasi penelitian yang juga merupakan sampel penelitian ialah laporan keuangan lima tahun terakhir (2014-2018). Pengumpulan data di lakukan dengan mengambil dokumentasi dari website resmi dan selanjutnya dianalisis dengan menggunakan metode EVA yang terdiri dari analisis NOPAT, Invested Capital, WACC, Capital Charges. Hasil penelitian menunjukkan bahwa Economic Value Added (EVA) pada PT. Blue Bird Tbk periode 2014-2018 mendapatkan nilai EVA < 0 artinya perusahaan tidak dapat menciptakan nilai tambah ekonomis (NITAMI). Di karenakan tingkat biaya modal lebih tinggi dibandingkan dengan tingkat pengembalian laba operasi perusahaan sebab adanya pesaing baru berupa transportasi online.

Kata kunci: Economic Value Added (EVA), NOPAT, Invested Capital, WACC, Capital Charges, Kinerja Keuangan.

1. PENDAHULUAN

\subsection{Latar Belakang}

Pengukuran kinerja keuangan ini dapat dinilai dengan menggunakan beberapa alat analisis,dalam penelitian ini yang digunakan yaitu metode EVA (Economic Value Added). Menurut Arifin, (2007) "EVA merupakan alat pengukuran kinerja perusahaan untuk menilai tingkat keberhasilan suatu kegiatan dari sisi kepentingan dan harapan penyandang dana (kreditur dan pemegang saham). Dengan demikian eksekutif dan manajer perusahaan dituntut untuk mampu menghasilkan keuntungan dari aktivitas perusahaan."

Metode Economic Value Added (EVA) ini merupakan salah satu alat untuk mengevaluasi kinerja perusahaan. Jika EVA lebih besar dari nol berarti perusahaan telah 
menciptakan nilai atau kekayaan untuk pemegang saham, sebaliknya jika EVA negatif maka akan merusak nilai perusahaan. Dan, banyak perusahaan yang menggunakan EVA karena memiliki beberapa kelebihan yang tidak dimiliki oleh metode lain, salah satunya adalah dapat digunakan secara mandiri tanpa membutuhkan data pembanding seperti standar industri atau data dari perusahaan lain. Oleh karena itu, kinerja keuangan jika di ukur dengan konsep EVA dapat menunjukkan pertimbangan dalam tingkat risiko perusahaan dan membantu pihak manajer untuk membuat keputusan investasi yang lebih baik.

Dari berbagai macam perusahaan jasa yang ada, salah satunya ialah perusahaan yang bergerak dibidang transportasi ini memiliki peran yang sangat penting dalam kehidupan sehari-hari. Salah satu dari perusahaan transportasi darat terbesar yang ada di Indonesia yaitu PT. Blue Bird Tbk. Berdasarkan beberapa berita atau media online mengabarkan bahwa PT. Blue bird Tbk mengalami masalah, yang membuat manajemen PT. Blue Bird Tbk terkesan mengalami penurunan pendapatan. Dapat dilihat laporan keuangan PT. Blue Bird Tbk mengenai laba bersih yang ada dalam laporan laba dari tahun 2014 sampai tahun 2018 yang di tampilkan dalam gambar berikut ini :

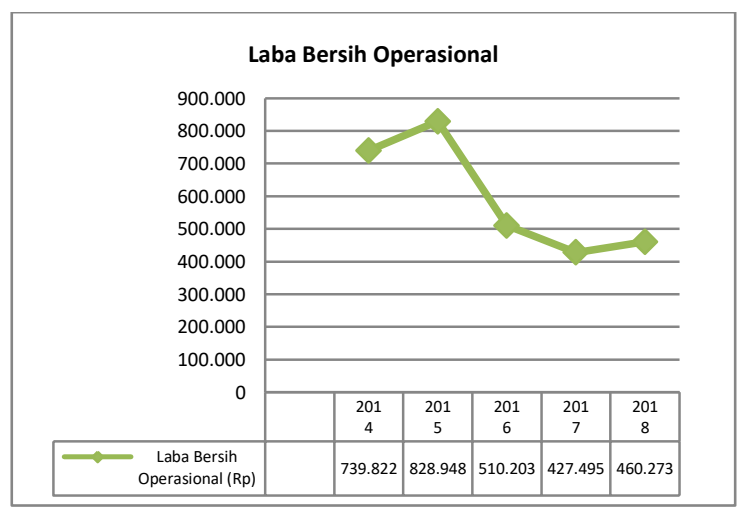

Sumber : www. Idx.co.id (Data Diolah)

Gambar 1. Laba Bersih Operasional (dalam jutaan rupiah) PT. Blue Bird Tbk Periode 2014-2018
Berdasarkan gambar diatas, laba bersih (Net Profit) PT. Blue Bird Tbk pada tahun 2014-2018 berfluktuasi. Dapat dilihat pada tahun 2014 laba bersih yang didapat sebesar Rp. 739.822.000.000 dan pada tahun 2015 mengalami peningkatan menjadi sebesar Rp. 828.948.000.000 tetapi pada 2016 mengalami penurunan yang sangat tajam dari tahun sebelumnya menjadi sebesar Rp. 510.203.000.000 pada tahun 2017 laba bersih menurun kembali menjadi sebesar Rp. 427.495.000.000 walaupun pada tahun 2018 laba bersih mengalami peningkatan menjadi sebesar Rp. 460.273.000.000.

Peneliti ingin melakukan penilaian kinerja keuangan pada perusahaan PT. Blue Bird Tbk tersebut, bertujuan untuk mengetahui perkembangan kinerja keuangan yang ada pada PT. Blue Bird Tbk apakah nilai kinerja keuangan perusahaan tersebut baik atau malah kurang baik.

\subsection{Rumusan Masalah}

Berdasarkan latar belakang yang telah diuraikan di atas, maka peneliti merumuskan masalah pada penelitian ini berupa bagaimana nilai kinerja keuangan dengan menggunakan metode Economic Value Added (EVA) pada PT. Blue Bird Tbk dari tahun 2014 sampai tahun 2018?

\subsection{Tujuan Penelitian}

Untuk menganalisis nilai kinerja keuangan dengan menggunakan metode Economic Value Added (EVA) pada PT. Blue Bird Tbk dari tahun 2014 sampai tahun 2018.

\section{TINJAUAN PUSTAKA}

\subsection{Landasan Teori}

\subsubsection{Manajemen Keuangan}

Menurut Jatmiko (2017:1) menyatakan bahwa"Manajemen Keuangan adalah kegiatan yang berkaitan dengan perencanaan, pengarahan, pemantauan, pengorganisasian dan pengendalian sumber daya keuangan suatu perusahaan. Manajemen keuangan adalah gabungan dua 
kata, yaitu "keuangan" dan "manajemen". Keuangan merupakan sumber kehidupan bagi perusahaan yang fokus dalam bidang bisnis." Dan dapat disimpulkan bahwa manajemen keuangan merupakan kegiatan yang dilakukan suatu perusahaan untuk mengetahui keadaan keuangan yang ada pada perusahaan tersebut.

\subsubsection{Rasio Keuangan}

Menurut Kasmir (2018:122) mengemukakan bahwa Rasio keuangan merupakan kegiatan membandingkan angka-angka yang ada dalam laporan keuangan. Perbandingan dapat dilakukan antara satu komponen dengan komponen dalam satu laporan keuangan atau antarkomponen yang ada diantara laporan keuangan. Kemudian, angka yang dibandingkan dapat berupa angka-angka dalam satu periode maupun beberapa periode.

\subsubsection{Kinerja Keuangan Perusahaan}

Menurut Pratiwi, M.D., Yaningwati, F., NP, M.G.W.E.(2014) menyatakan bahwa "Kinerja keuangan perusahaan adalah prestasi yang dicapai perusahaan dalam suatu periode tertentu dan merupakan salah satu dasar penilaian mengenai kondisi keuangan perusahaan yang menjadi tolak ukur untuk mengetahui seberapa efektif dan efisien manajer atau perusahaan dalam mencapai tujuannya." Sedangkan menurut Kariyoto, (2017:107) Financial Performance ialah hasil aktivitas operasi perusahaan yang disajikan dalam bentuk angka-angka keuangan. Hamzah (2018) menyatakan pengukuran kinerja adalah penentuan secara periodik tampilan perusahaan yang berupa kegiatan operasional, struktur organisasi, dan karyawan yang berdasarkan sasaran, standar dan kriteria yang telah ditetapkan sebelummya.

Hasil aktivitas perusahaan periode sekarang harus dikomparasikan dengan:
1. Financial Performance periode masa lalu.

2. Anggaran neraca dan rugi keuntungan,

3. Rata-rata Financial Performance perusahaan sejenis.

Berdasarkan pengertian diatas, dapat disimpulkan bahwa kinerja keuangan perusahaan merupakan salah satu dasar penilaian yang dilakukan untuk mengukur tingkat kesehatan pada perusahaan tersebut.

\subsubsection{Biaya Modal}

Menurut Nofiyanti, N., Sunarko, B., Widiastuti, E.(2016) Biaya Modal adalah biaya yang harus ditanggung oleh perusahaan karena menggunakan sumber dana tertentu, setiap sumber dana baik itu modal sendiri maupun pinjaman mempunyai biaya modal. Sedangkan menurut Buyung, R.A.H.F., Pratasis, P.A.K., Malingkas, G.Y.(2019) menyatakan bahwa Biaya Modal adalah jumlah semua pengeluaran yang dibutuhkan mulai dari pra studi sampai proyek selesai dibangun. Dari beberapa pengertian diatas, dapat disimpulkan bahwa biaya modal merupakan biaya yang ditanggung oleh perusahaan untuk membayarkan modal yang telah dipakai, baik itu berasal dari hutang, modal sendiri maupun laba ditahan untuk membiayai investasi perusahaan.

\subsubsection{Metode Economic Value Added (EVA)}

Economic Value Added (EVA) merupakan salah satu metode pengukuran kinerja yang ditemukan pertama kali oleh G. Bennet Stewart dan Joel M. Stren. Mereka berdua merupakan seorang analis keuangan dari perusahaan Sten Stewart dan Co pada tahun 1993. EVA merupakan salah satu metode yang mengukur kinerja keuangan perusahaan untuk menentukan investasi di suatu perusahaan. Manfaat dari EVA sebagai tolak ukur dalam menilai kinerja keuangan bagi para pemilik modal yang berminat menginventasikan modalnya di perusahaan. Di Indonesia metode EVA 
dikenal dengan sebutan metode NITAMI (Nilai Tambah Ekonomi).

Menurut Suripto (2015:19) EVA merupakan ukuran sejauh mana perusahaan menciptakan nilai tambah secara ekonomis bagi pemegang saham. Dan menurut Tunggal (2008:1) Economic Value Added (EVA) adalah suatu sistem manajemen keuangan untuk mengukur laba ekonomi dalam suatu perusahaan yang menyatakan bahwa kesejahteraan hanya dapat tercipta jika perusahaan mampu memenuhi semua biaya operasi (operating cost) dan biaya modal (cost of capital). Sedangkan menurut Arifin, (2007) EVA merupakan alat pengukuran kinerja perusahaan untuk menilai tingkat keberhasilan suatu kegiatan dari sisi kepentingan dan harapan penyandang dana (kreditur dan pemegang saham).

Menurut Suripto (2015:64) ada beberapa cara untuk meningkatkan nilai Economic Value Added (EVA) perusahaan yaitu:

a. Peningkatan NOPAT dengan meningkatnya pendapatan operasional

b. Mengurangi biaya modal dengan mengurangi modal perusahaan dan biaya modal.

\subsubsection{Manfaat EVA (Econimoc Value Added)}

Terdapat beberapa manfaat yang dapat diperoleh perusahaan dalam menggunakan EVA sebagai alat ukur kinerja dan nilai tambah perusahaan. Menurut Tunggal (2008), beberapa manfaat EVA dalam mengukur kinerja perusahaan antara lain :

1. Dapat digunakan sebagai penilai kinerja perusahaan yang berfokus pada penciptaan nilai (value creation).

2. Dapat meningkatkan kesadaran manajer bahwa tugas mereka adalah untuk memaksimumkan nilai perusahaan serta nilai pemegang saham.

3. Dapat membuat para manajer berfikir dan juga bertindak seperti halnya pemegang saham yaitu memilih investasi yang memaksimumkan tingkat pengembalian dan meminimumkan tingkat biaya modal sehingga nilai perusahaan dapat dimaksimumkan.

4. EVA membuat para manajer agar memfokuskan perhatian pada kegiatan yang menciptakan nilai dan memungkinkan mereka untuk mengevaluasi kinerja berdasarkan kriteria maksimum nilai perusahaan.

5. EVA sebagai motivator perusahaan untuk lebih memperhatikan kebijaksanaan struktur modalnya.

6. EVA dapat digunakan sebagai alat untuk mengidentifikasi proyek atau kegiatan yang memberikan pengembalian yang lebih tinggi dari pada biaya modal.

\subsection{Kerangka Pemikiran}

Laporan Keuangan PT. Blue Bird Tbk Tahun 2014-2018

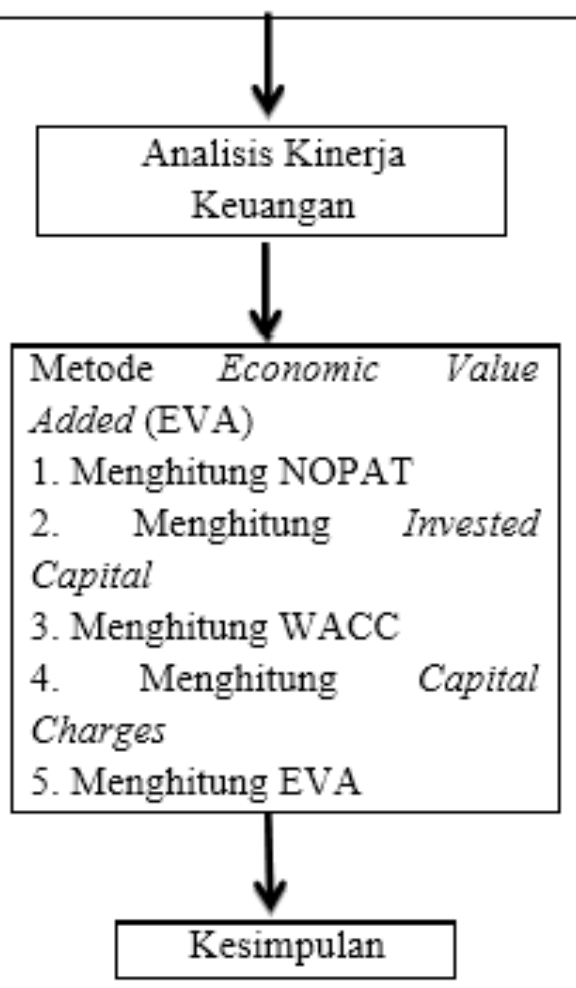

Gambar 2. Kerangka Pemikiran 
3. METODE PENELITIAN

\subsection{Jenis Penelitian}

Berdasarkan karakteristiknya, penelitian ini termasuk penelitian deskriptif. Metode ini disebut metode kuantitatif karena data penelitian berupa angka-angka dan analisis menggunakan statistik (Sugiyono,2013:7). Jadi, dalam penelitian ini peneliti menggunakan metode deskriptif pendekatan kuantitatif, penelitian ini terdapat satu variabel yaitu kinerja keuangan.

\subsection{Variabel Penelitian}

Menurut Ridha, N. (2017:66) menyatakan bahwa "Variabel penelitian adalah suatu atribut, nilai / sifat dari objek, individu/kegiatan yang mempunyai banyak variasi tertentu antara satu dan lainnya yang telah ditentukan oleh peneliti untuk dipelajari dan dicari informasinya serta ditarik kesimpulannya." Maka, variabel penelitian yang digunakan dalam penelitian ini yaitu Kinerja Keuangan PT. Blue Bird Tbk.

\subsection{Lokasi dan Waktu}

Penelitian ini dilakukan dengan mengambil data sekunder yang diperoleh dari website resmi Bursa Efek Indonesia (wwwidx.co.id), www.bluebirdgroup.com, serta web atau situs yang terkait dengan penelitian.

Penelitian ini dilaksanakan pada bulan September 2019 hingga Februari 2020.

\subsection{Objek Penelitian}

Menurut Anshori, M., Iswati, S. (2017: 114) menyatakan bahwa objek penelitian adalah sesuatu yang dikenai penelitian atau sesuatu yang diteliti. Dalam penelitian kuantitatif, objek penelitian adalah variabel yang diteliti.

Maka dalam penelitian ini yang menjadi obyek penelitian ialah data berupa laporan keuangan PT. Blue Bird Tbk tahun 2014-2018.

\subsection{Populasi dan Sampel}

Penulis melakukan pembatasan jumlah populasi yaitu seluruh laporan keuangan PT. Blue Bird Tbk dari tahun 2014 sampai tahun 2018

Pengertian sampel menurut Sugiyono (2013:81) "Sampel adalah bagian dari jumlah dan karakteristik yang dimiliki oleh populasi tersebut." Dari pengertian tersebut, dapat disimpulkan bahwa sampel merupakan sebagian jumlah yang dimiliki oleh populasi.

Sampling jenuh adalah teknik penentuan sampel bila semua anggota populasi digunakan sebagai sampel (Sugiyono, 2013:85). Dari pengertian tersebut, dapat disimpulkan bahwa teknik sampling yang menggunakan seluruh jumlah populasi sebagai sampel dikategorikan sebagai teknik sampling jenuh.

Maka dengan itu, menggunakan teknik sampling jenuh sebagai dasar penentuan jumlah sampel yang diteliti, sampel diambil dari laporan keuangan PT. Blue Bird Tbk tahun 2014 sampai dengan tahun 2018.

\subsection{Teknik Pengumpulan Data}

Dalam penelitian ini data yang di gunakan data sekunder, yaitu:

a. Di dapat dari laporan-laporan keuangan yang diperoleh dari website Bursa Efek Indonesia (BEI) tahun 2014-2018, khususnya laporan Laba/Rugi dan posisi.

\begin{tabular}{|c|c|}
\hline Tingkat & Total Hutang \\
\hline Modal & Total Hutang \& \\
\hline
\end{tabular}

$\begin{array}{ll}\begin{array}{l}\text { Cost Of } \\ \text { Debt } \\ (\text { rd })=\end{array} & \text { Beban Bunga } \\ & \text { Total Hutang }\end{array}$


b. Di dapat dari buku, jurnal, website resmi agar mendapatkan acuan teori yang memiliki landasan yang jelas untuk melengkapi data.

\subsection{Teknik Analisis Data}

Teknik analisis data yang digunakan analisis kuantitatif yaitu analisis data yang Tahap-tahap kuantitatif untuk menentukan Economic Value Added (EVA) adalah sebagai berikut :

\section{a. Menghitung NOPAT Operating After Tax)}

(Net

Menurut Tunggal (2008:4), NOPAT merupakan laba bersih setelah pajak, mengukur laba yang diperoleh perusahaan dan operasi bersih. NOPAT pada dasarnya merupakan tingkat keuntungan yang diperoleh dari modal yang ditanam dan biaya modal adalah biaya dari modal yang ditanamkan, maka NOPAT dan biaya modal bisa dirumuskan sebagai berikut:

$$
\text { NOPAT }=\text { EBIT }- \text { TAX }
$$

dimana:

a. $\quad$ NOPAT $=$ Net Operating After Tax (laba operasional bersih setelah pajak).

b. $\quad$ EBIT = Earnings Before Interest and Taxes (laba sebelum bunga dan pajak atau biasa disebut pendapatan operasional).

c. TAX = Pajak (pengorbanan yang dikeluarkan oleh perusahaan dalam penciptaan nilai dalam perhitungan EVA).

\section{b. Menghitung Invested Capital}

Interested Capital dihitung dari jumlah hutang bank jangka pendek, pinjaman bank atau sewa guna usaha yang jatuh tempo dalam satu tahun, kewajiban pajak tangguhan, kewajiban jangka panjang atas aktiva perusahaan dan ekuitas. Dirumuskan sebagai berikut:

Invested Capital $=$ Total Hutang \& Ekuitas - Hutang Jangka Pendek dimana:
a. Invested Capital
$=$ Menghitung
modal yang di investasikan.

b. Total Hutang \& Ekuitas = Menunjukkan beberapa bagian dari modal sendiri yang dijadikan jaminan utang.

c. Hutang jangka pendek = penjaminan jangka pendek tanpa bunga merupakan pinjaman yang digunakan yang pelunasan atau pembayarannya akan dilakukan dalam jangka pendek (satu tahun sejak tanggal neraca), menggunakan aktiva lancar yang dimiliki perusahaan, dan atas pinjaman itu tidak dikenal bunga, seperti hutang usaha, hutang pajak, biaya yang masih dibayar, dan lain-lain.

\section{c. Menghitung WACC (Weight Average Cost of Capital)}

WACC sama dengan jumlah biaya dari setiap komponen modal-utang jangka pendek, utang jangka panjang, dan ekuitas pemegang saham ditimbang berdasarkan proporsi relatifnya dalam struktur modal perusahaan pada nilai pasar, maka WACC bisa dirumuskan sebagai berikut :

$$
\text { WACC }=\{(\text { D x rd })(1-\text { Tax })+(\text { E x re })\}
$$

\begin{tabular}{|c|c|c|}
\hline \multirow{2}{*}{ Tingkat Modal (D) = } & Total Hutang & \multirow{2}{*}{ x 100\% } \\
\hline & Total Hutang\&Ekuitas & \\
\hline \multirow{2}{*}{ Cost OfDebt $(\mathrm{rd})=$} & Beban Bunga & \multirow{2}{*}{$\mathrm{x} 100 \%$} \\
\hline & Total Hutang & \\
\hline \multirow{2}{*}{$\begin{array}{l}\text { Tingkat Modal \& } \\
\text { Ekuitas }(\mathrm{E})=\end{array}$} & Total Ekuitas & \multirow{2}{*}{$\mathrm{x} 100 \%$} \\
\hline & Total Hutang\&Ekuitas & \\
\hline \multirow[t]{2}{*}{ Cost of Equity $(\mathrm{re})=$} & $\begin{array}{l}\text { Laba Bersih Setelah } \\
\text { Pajak }\end{array}$ & \multirow[t]{2}{*}{$\times 100 \%$} \\
\hline & Total Ekuitas & \\
\hline \multirow[b]{2}{*}{ Tingkat Pajak $(T a x)=$} & Beban Pajak & \multirow[b]{2}{*}{ x $100 \%$} \\
\hline & $\begin{array}{l}\text { Laba Bersih Sebelum } \\
\text { Pajak }\end{array}$ & \\
\hline
\end{tabular}

dimana:

\section{d. Menghitung Capital Charges}

Capital Charges diperoleh dengan cara mengkalikan WACC (Weighted Average Cost of Capital) dengan Invested Capital. Capital Charges menunjukkan seberapa besar kesempatan modal yang telah di investasikan kreditur. Tunggal (2008:3), menambahkan Capital Charges merupakan 
aliran kas yang dibutuhkan untuk mengganti para investor atas resiko usaha dari modal yang ditanamkan. Dirumuskan sebagai berikut :

Capital Charges $=$ WACC $\mathrm{x}$ Invested Capital

dimana:

a. Capital Charges $=$ menunjukkan seberapa besar kesempatan modal yang telah di investasikan kreditur.

b. WACC = rata-rata tertimbang (Weighted Average Cost of Capital).

c. Invested Capital $=$ Menghitung modal yang di investasikan.

\section{e. Menghitung Economic Value Added (EVA)}

EVA merupakan suatu tolak ukur kinerja keuangan yang berbasis nilai. EVA merupakan suatu tolak ukur yang menggambarkan jumlah absolute dari nilai pemegang saham (shareholder value) yang di ciptakan (Created) atau di rusak (destroyed) pada suatu periode tertentu. EVA yang positif menunjukan penciptaan nilai (value creation), sedangkan EVA yang negative menunjukan penghancuran nilai (value destruction).

\section{EVA $=$ NOPAT - Capital Charges} dimana:

a. EVA $=$ Economic Value Added (mengukur nilai tambah yang dihasilkan suatu perusahaan).

b. $\quad$ NOPAT $=$ Net Operating After Tax (laba operasional bersih setelah pajak)

c. Capital Charges $=$ menunjukkan seberapa besar kesempatan modal yang telah di investasikan kreditur.

\section{HASIL DAN PEMBAHASAN}

\subsection{Perhitungan NOPAT}

Tujuan dari menghitung Net Operating Profit After Tax (NOPAT) untuk mengetahui seberapa besar peningkatan laba bersih yang diperoleh laba operasi perusahaan setelah dikurangi pajak penghasilan. Berikut perhitungan laba bersih setelah pajak yang diperoleh dari PT. Blue Bird Tbk periode 2014-2018 dapat dilihat pada tabel dan hasil pertumbuhan NOPAT dari tahun ke tahun yang dapat dilihat pada gambar.

Tabel 1. Hasil NOPAT PT. BLUE BIRD TBK Periode 2014-2018 (dalam jutaan rupiah)

\begin{tabular}{|c|c|c|c|}
\hline \multirow{2}{*}{ Tahun } & \multicolumn{1}{|c|}{ EBIT } & \multicolumn{1}{c|}{$T A X$} & NOPAT \\
\cline { 2 - 4 } & (A) & (B) & (A-B) \\
\hline 2014 & 986.528 & 246.706 & 739.822 \\
\hline 2015 & 1.104 .892 & 275.944 & 828.948 \\
\hline 2016 & 691.811 & 181.608 & 510.203 \\
\hline 2017 & 562.177 & 134.682 & 427.495 \\
\hline 2018 & 606.175 & 145.902 & 460.273 \\
\hline
\end{tabular}

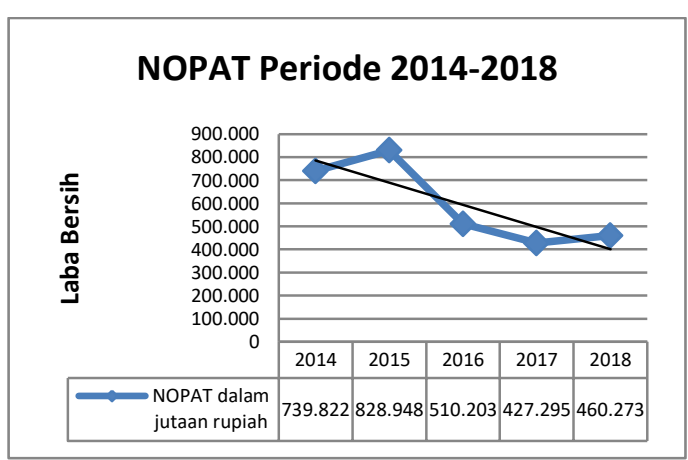

Sumber: Data diolah 2019

Sesuai garis trend diatas NOPAT cenderung mengalami penurunan karena keuangan PT. Blue Bird Tbk mengalami fluktuasi yang disebabkan adanya transportasi online, membuat perusahaan tersebut menurun laba bersihnya namun pada tahun terakhir yang diteliti mengalami peningkatan dari tahun sebelumnya.

Besarnya NOPAT pada PT. Blue Bird Tbk selama 5 periode lalu mengalami fluktuasi yaitu pada tahun 2014 sebesar Rp 739.822.000.000 pada tahun 2015 mengalami peningkatan menjadi sebesar Rp 828.948.000.000 pada tahun 2016 mengalami penurunan yang drastis dari tahun sebelumnya menjadi sebesar Rp 510.203.000.000 terjadi penurunan juga 
pada tahun 2017 yang menjadi sebesar Rp 427.495.000.000 dan pada tahun 2018 mengalami sedikit peningkatan dari tahun sebelumnya menjadi sebesar Rp 460.273.000.000.

\subsection{Perhitungan Invested Capital}

Tabel 2. Hasil Invested Capital PT. BLUE BIRD TBK Periode 2014-2018 (dalam jutaan rupiah)

\begin{tabular}{|c|r|r|r|}
\hline Tahun & $\begin{array}{c}\text { Total } \\
\text { Hutang \& } \\
\text { Ekuitas (A) }\end{array}$ & $\begin{array}{c}\text { Hutang } \\
\text { Jangka } \\
\text { Pendek (B) }\end{array}$ & $\begin{array}{c}\text { Invested } \\
\text { Capital }(A-B)\end{array}$ \\
\hline 2014 & 7.171 .511 & 1.440 .545 & 5.730 .966 \\
\hline 2015 & 7.153 .055 & 964.508 & 6.188 .547 \\
\hline 2016 & 7.300 .612 & 814.103 & 6.486 .509 \\
\hline 2017 & 6.516 .487 & 435.947 & 6.080 .540 \\
\hline 2018 & 6.955 .157 & 614.987 & 6.340 .170 \\
\hline
\end{tabular}

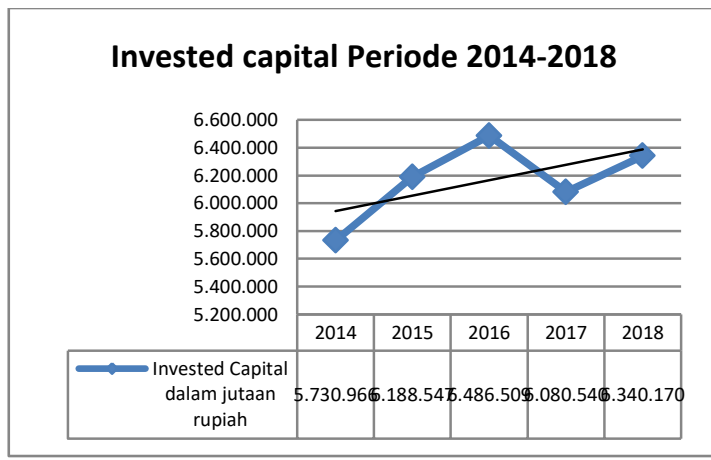

Sumber: Data diolah 2019

Sesuai dengan garis tendr, menunjukan bahwa Invested Capital cenderung mengalami peningkatan. Hali ini karena PT Blue Bird Tbk terpengaruh oleh adanya tranportasi online, sehingga terlihat pada tahun 2016 perusahaan mengalami penurunan tajam yang akhirnya mengalalami lonjakan pinjaman.

Perhitungan diatas besarnya Invested Capital pada PT. Blue Bird Tbk selama 5 periode lalu mengalami fluktuasi yaitu pada tahun 2014 sebesar

$\mathrm{Rp}$ 5.730.966.000.000 pada tahun 2015 meningkat menjadi sebesar $\quad \mathrm{Rp}$ 6.188.547.000.000 pada tahun 2016 juga mengalami peningkatan menjadi sebesar $\mathrm{Rp}$
6.486.509.000.000 terjadi penurunan yang drastis pada tahun 2017 menjadi sebesar Rp 6.080.540.000.000 tetapi pada tahun 2018 mengalami peningkatan kembali menjadi sebesar $\quad \mathrm{Rp} 6.340 .170 .000 .000$.

\subsection{Perhitungan WACC}

Tabel 3. Hasil WACC PT. BLUE BIRD Tbk

\begin{tabular}{|c|c|c|c|}
\hline Tahun & WACC & $\begin{array}{c}\text { INVESTED } \\
\text { CAPITAL } \\
(\mathrm{A})\end{array}$ & $\begin{array}{c}\text { CAPITAL } \\
\text { CHARGES } \\
(\mathrm{A} \times \mathrm{B})\end{array}$ \\
\hline 2014 & 0,133 & 5.730 .966 & 762.218 \\
\hline 2015 & 0,139 & 6.188 .547 & 860.208 \\
\hline 2016 & 0,091 & 6.486 .509 & 590.272 \\
\hline 2017 & 0,081 & 6.080 .540 & 492.524 \\
\hline 2018 & 0,073 & 6.340 .170 & 462.832 \\
\hline
\end{tabular}

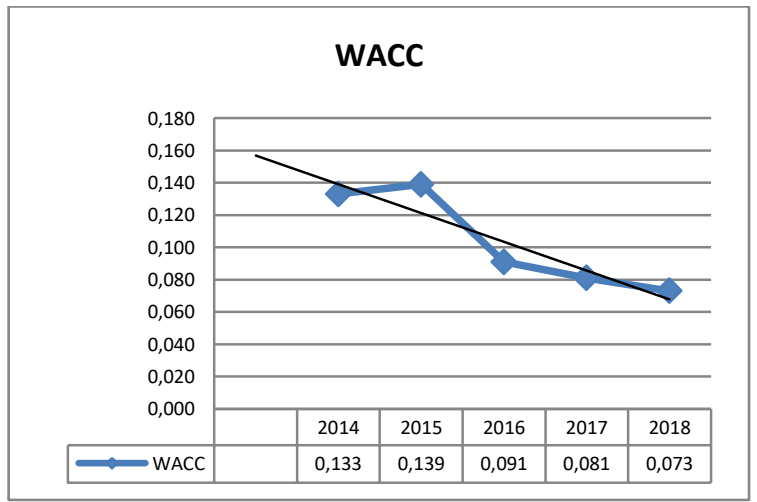

Sumber: Data diolah 2019

Sesuai garis trend diatas WACC cenderung mengalami penurunan karena keuangan PT. Blue Bird Tbk mengalami fluktuasi yang disebabkan adanya transportasi online, membuat perusahaan tersebut menurun biaya modal untuk pengembalian modal investasi kepada investor, namun pada tahun terakhir yang diteliti mengalami peningkatan dari tahun sebelumnya.

Dapat dilihat yang memiliki nilai WACC yang paling tinggi yaitu pada tahun 2015 sebesar 0,139 sedangkan nilai yang paling rendah adalah pada tahun 2018 sebesar 0,073 dari tahun 2016 sampai tahun 2018 nilai WACC yang di dapat terus 
menurun yaitu pada tahun 2016 mengalami penurunan yang drastis dari tahun sebelumnya sebesar 0,091 pada tahun 2017 sebesar 0,081 dan pada tahun 2018 sebesar 0,073

\subsection{Perhitungan Capital Charges}

Tabel 4. Hasil Capital Charges PT. BLUE BIRD TBK Periode 2014-2018

\begin{tabular}{|c|r|r|r|r|r|r|}
\hline Tahun & $\begin{array}{c}\text { Tingkat } \\
\text { Modal } \\
\text { (D) }\end{array}$ & $\begin{array}{c}\text { Cost Of } \\
\text { Debt (Rd) }\end{array}$ & 1-tax & $\begin{array}{c}\text { Tingkat } \\
\text { Modal \& } \\
\text { Eluitas (E) }\end{array}$ & $\begin{array}{c}\text { Cost Of } \\
\text { Equity } \\
(r e)\end{array}$ & $\begin{array}{c}\text { WACC } \\
\text { (Dxrd)(1- } \\
\text { tax })+(\text { Exre })\}\end{array}$ \\
\hline 2014 & $49,76 \%$ & $7,92 \%$ & $74,99 \%$ & $50,24 \%$ & $20,53 \%$ & 0,133 \\
\hline 2015 & $39,49 \%$ & $7,80 \%$ & $75,03 \%$ & $60,51 \%$ & $19,15 \%$ & 0,139 \\
\hline 2016 & $36,13 \%$ & $8,08 \%$ & $73,75 \%$ & $63,87 \%$ & $10,94 \%$ & 0,091 \\
\hline 2017 & $24,33 \%$ & $8,37 \%$ & $76,04 \%$ & $75,67 \%$ & $8,67 \%$ & 0,081 \\
\hline 2018 & $24,30 \%$ & $3,87 \%$ & $75,93 \%$ & $75,70 \%$ & $8,74 \%$ & 0,073 \\
\hline
\end{tabular}

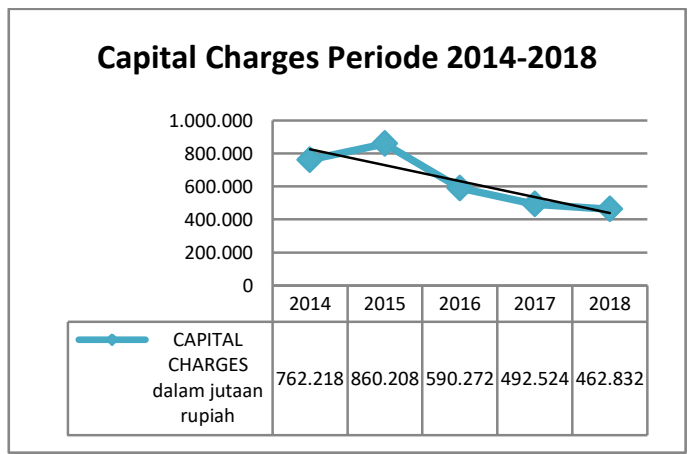

Sumber: Data diolah 2019

Sesuai garis trend diatas Capital Charges cenderung mengalami penurunan karena keuangan PT. Blue Bird Tbk mengalami fluktuasi yang disebabkan adanya transportasi online, membuat perusahaan tersebut menurun investasinya.

Dapat dilihat bahwa pada tahun 2015 capital charges yang didapat sebesar $\mathrm{Rp}$ 762.218.000.000 dan pada tahun 2016 mengalami peningkatan menjadi sebesar Rp 860.208.000.000 tetapi dari tahun 2016 sampai tahun 2018 mengalami penurunan dari tahun ke tahun yaitu pada tahun 2016 mengalami penurunan yang drastis dari tahun sebelumnya menjadi sebesar Rp 590.272.000.000 pada tahun 2017 mengalami penurunan menjadi sebesar $\mathrm{Rp}$ 492.524.000.000 dan pada tahun 2018 turun menjadi sebesar Rp 462.832.000.000.

\subsection{Perhitungan Economic Value Added (EVA)}

\begin{tabular}{|c|c|c|c|}
\hline \multirow{2}{*}{ Tahun } & NOPAT & $\begin{array}{c}\text { CAPITAL } \\
\text { CHARGES }\end{array}$ & EVA \\
\cline { 2 - 4 } & $(\mathrm{A})$ & $(\mathrm{B})$ & \multicolumn{1}{c|}{$(\mathrm{A}-\mathrm{B})$} \\
\hline 2014 & 739.822 & 762.218 & -22.396 \\
\hline 2015 & 828.948 & 860.208 & -31.260 \\
\hline 2016 & 510.203 & 590.272 & -80.069 \\
\hline 2017 & 427.495 & 492.524 & -65.029 \\
\hline 2018 & 460.273 & 462.832 & -2.559 \\
\hline
\end{tabular}

Tabel 5. Hasil EVA PT. BLUE BIRD TBK

Periode 2014-2018 (dalam jutaan rupiah)

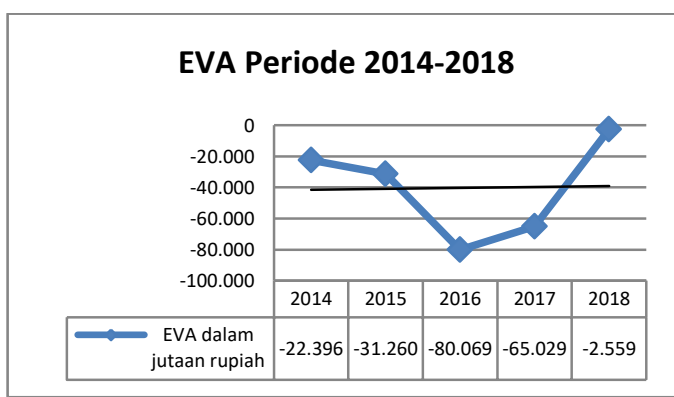

Sumber: Data diolah 2019

Sesuai garis trend diatas Economic Value Added (EVA) cenderung meningkat walaupun tidak terlalu terlihat karena keuangan PT. Blue Bird Tbk mengalami fluktuasi yang disebabkan adanya transportasi online, membuat perusahaan tersebut mendapat nilai kinerja keuangannya kurang baik, namun pada tahun 2018 mengalami kenaikan yang tinggi dari sebelumnya.

Dari data tabel dan gambar yang ada dapat dilihat bahwa nilai EVA yang di peroleh PT. Blue Bird Tbk dari hasil perhitungan dan analisis tersebut yaitu EVA $<0$, yang berarti perusahaan tidak dapat menciptakan nilai tambah pada perusahaan. Laba yag diterima tidak bisa memenuhi harapan para pemegang saham yaitu tidak mendapatkan pengembalian yang setimpal dengan investasi yang ditanamkan, sehingga dengan tidak ada 
nilai tambah yang dihasilkan mengidentifikasikan bahwa kinerja keuangan perusahaan kurang baik, namun pada tahun terakhir penelitian mengalami kenaikan.

Dari data di atas nilai Economic Value Added (EVA) pada tahun 2014 sebesar Rp -22.396.000.000, pada tahun 2015 kembali mengalami penurunan sebesar Rp 31.260.000.000 dan mengalami penurunan yang sangat tajam pada tahun 2016 sebesar Rp -80.069.000.000, pada tahun 2017 kembali mengalami penurunan sebesar Rp -65.029.000.000 tetapi pada tahun 2018 nilai EVA yang dihasilkan sangat meningkat dari tahun sebelumnya sebesar Rp -2.559.000.000.

Hal ini disebabkan oleh adanya persaingan yang terjadi pada tahun 2016 dengan taksi yang berbasis online membuat perusahaan transportasi konvensional mengalami penurunan yang sangat signifikan terhadap keuangan, banyak perusahaan transportasi konvensional menutup usahanya karena tidak sanggup dengan persaingan tersebut. PT. Blue Bird Tbk ini walaupun mengalami penurunan pada tahun 2016 sampai tahun 2017. Tahun 2018 mengalami peningkatan karena usahanya dalam memajukan perusahaan dengan membuat inovasi lain, dapat terlihat pada hasil nilai EVA bahwa 2018 ada peningkatan dari tahun sebelumnya. Maka agar perusahan dapat mempertahankan kelangsungannya perlu melakukan inovasiinovasi baru dan dengan menjalin kerjasama dengan pihak transportasi online serta travel.

\section{KESIMPULAN DAN SARAN}

\subsection{Kesimpulan}

Berdasarkan hasil penelitian yang telah dijelaskan sebelumnya, maka dapat diambil kesimpulan bahwa kinerja keuangan PT. Blue Bird Tbk periode 2014 sampai dengan 2018 yang dianalisis dengan menggunakan metode Economic Value Added (EVA) atau nilai tambah ekonomis (NITAMI) yang sesuai dengan kriteria dalam EVA menunjukkan hasil kurang baik.

Kinerja keuangan pada PT. Blue Bird Tbk periode 2014-2018 yang dihasilkan ialah bernilai negatif (EVA < 0), dikarenakan menunjukkan perusahaan tidak dapat menciptakan nilai tambah ekonomis (NITAMI) bagi perusahaan, dapat dilihat dari data nilai Economic Value Added (EVA) pada tahun 2014 sebesar Rp. 22.396.000.000 dapat dilihat juga pada tahun 2015 sebesar Rp. -31.260.000.000 pada tahun 2016 sebesar Rp. 80.069.000.000 pada tahun 2017 sebesar Rp. -65.029.000.000 dan pada tahun 2018 nilai EVA nya sebesar Rp. -2.559.000.000. Hal ini dikarenakan tingkat biaya modal lebih tinggi dibandingkan dengan tingkat pengembalian laba operasi perusahaan sebab adanya pesaing baru berupa transportasi online, tetapi pada tahun 2018 mengalami peningkatan dari tahun sebelumnya maka ada kemungkinan akan membaik.

\subsection{Saran}

Melalui penelitian ini, peneliti dapat memberikan saran antara lain:

1. Bagi peneliti selanjutnya, diharapkan seperti MVA yang dapat mempengaruhi kinerja keuangan dan memperluaskan objek serta periode pengamatan sehingga jumlah data yang digunakan akan semakin banyak.

2. Bagi PT. Blue Bird Tbk, dengan hasil perhitungan menggunakan metode Economic Value Added (EVA) ini hendaknya akan mendorong perusahaan untuk terus meningkatkan pendapatan agar kinerja keuangan di masa yang akan datang meningkat dengan cara terus memberikan inovasiinovasi baru dalam pelayanan jasa maupun dalam bentuk transportasinya, membuat iklan yang dapat menarik minat pelanggan, dan dengan cara menjalin kerjasama dengan pihak transportasi online serta travel 
manapun untuk menambah jaringan koneksi bisnisnya, supaya PT. Blue Bird Tbk dapat memperbaiki nilai kinerja keuangannya serta agar tetap bisa bertahan dalam persaingan yang terjadi.

3. Ada baiknya pihak manajemen PT. Blue Bird Tbk secara berkala dalam perbulan, per triwulan atau pun per tahun untuk secara khusus membuat atau melaporkan biaya-biaya yang telah dikeluarkan untuk mengindentifikasi pemborosan dalam aktivitas yang tidak menambah nilai, dan dengan cara mencari modal dari tempat-tempat yang bunga pinjamannya kecil untuk menurunkan biaya modal dalam perusahaan.

\section{DAFTAR PUSTAKA}

Abdullah, F.M. (2003). Manajemen Perbankan Edisi Ketiga. UMM Press, Malang.

Anshori, M., Iswati, S. (2017). Metodologi Penelitian Kuantitatif. Airlangga University Press, Surabaya.

Ariefiansyah, R., Utami, M.M. (2013). Membuat Laporan Keuangan Gampang. Dunia Cerdas, Jakarta.

Arifin, J. (2007). Cara Cerdas Menilai Kinerja Perusahaan (Aspek Finansial \& Non Finansial) Berbasis Komputer. PT. Elex Media Komputindo, Jakarta.

Barus, M.A., Sudjana, N., Sulasmiyati, S. (2017). Penggunaan Rasio Keuangan Untuk Mengukur Kinerja Keuangan Perusahaan (Studi pada PT. Astra Otoparts, Tbk dan PT. Goodyer Indonesia, Tbk yang Go Public di Bursa Efek Indonesia). Jurnal Administrasi Bisnis (JAB). Vol.44(1):155.

Buyung, R.A.H.F., Pratasis, P.A.K., Malingkas, G.Y. (2019). Life Cycle Cost (LCC) Pada Proyek Pembangunan Gedung Akuntansi Universitas Negeri Manado (UNIMA)
Di Tondano. Jurnal Sipil Statik. Vol.7(11):1529.

Fatin, R. (2017). Pengaruh Economi Value Added (EVA), Market Value Added (MVA), Kebijakan Dividen, Dan Beta Pasar Terhadap Return Saham Pada Perushaan Manufaktur Yang Terdaftar Di Bursa Efek Indonesia Periode 2011-2015. Skripsi. Yogyakarta: Fakultas Ekonomi.

Feranita, R. (2017). Analisis Kinerja Keuangan Dengan Menggunakan Metode EVA (Studi Kasus Pada Perusahaan Sektor Pertanian Yang Terdaftar Di ISSI). Skripsi. Palembang: Fakultas Ekonomi Dan Bisnis Islam.

Hamzah, Z. Z., \& Nurjanah, R. (2018). Analisis Rasio Likuiditas, Rentabilitas dan Solvabilitas untuk menilai Kinerja Keuangan PT Bakrie Sumatra Plantations Tbk. Economicus, 12(2).

Hery. 2016. Analisis Laporan Keuangan.

Cetakan pertama. PT. Gramedia, Jakarta.

Jatmiko, D.P. 2017. Pengantar Manajemen Keuangan. Diandra kreatif. Yogyakarta.

Kariyoto. 2017. Analisa Laporan Keuangan. Cetakan pertama. Universitas Brawijaya Media, Malang. Kasmir. 2018. Analisis Laporan Keuangan. Cetakan kesebelas. Rajawali Pers, Depok.

Kusumawati, E. (2017). Analisis Kinerja Keuangan Berdasarkan Metode EVA Pada PT. Pegadaian (Persero) Cabang Panakkukang Di Kota Makassar. Skripsi. Makassar: Fakultas Ekonomi.

Lestari, N., Hidayatullah. (2018). Determinan Biaya Modal: Studi Pada Perusahaan Non-Keuangan. Jurnal Bisnis dan Manajemen. Vol.8(2):141

Mamarimbing, J.M., Sepang, J.L., Mintardjo, C.M.O. (2016). Analisis Sensitivitas Market Risk Pada Perusahaan Sektor Prbankan (Bank- 
Bank BUMN) Periode 2011-2014.

Jurnal EMBA. Vol. 4(2):795

Margaretha, Farah. (2007). Manajemen

Keuangan. Edisi Kedua. Cetakan

Kedua. Gramedia Widiasarana

Indonesia, Jakarta

Mirza, T. (1997). EVA Sebagai Alat Penilaian. Usahawan, Jakarta.

Nofiyanti, N., Sunarko, B., Widiastuti, E. (2016). Analisis Kelayakan Investasi Dalam Rangka Ekspansi (Studi Kasus Pada PDAM Tirta Satria Kabupaten Banyumas). Jurnal Performance. Vol. 23(1):4

Pratiwi, M. D., Yaningwati, F., NP, M, G, W, E. (2014). Penilaian Kinerja Keuangan Perusahaan Dengan Analisis Rasio Keuangan Dan Metode Economic Value Added (EVA) (Studi pada PT. Berlina, Tbk dan Anak Perusahaan yang Terdaftar di Bursa Efek Indonesia Periode 2010-2012). Jurnal Administrasi Bisnis. Vol. 9( 2):3

Rahmi. (2018). Analisis Economic Value Added (EVA) Pada Perusahaan Sektor Industri Yang Terdaftar Di Jakarta Islamic Index (JII). Skripsi. Banda Aceh: Fakultas Ekonomi Dan Bisnis Islam.

Website :

https://databoks.katadata.co,id/datapublish/ 2018/03/26/kehadiran-transportasionline-tekan-pendapatan-taksikonvensional. (diakses pada tanggal 1 November 2019) 